Brit. J. vener. Dis. (1955), 31, 186.

\title{
ERYTHROMYCIN AND TETRACYCLINE HYDROCHLORIDE IN THE TREATMENT OF NON-GONOCOCCAL URETHRITIS * $\uparrow$ \\ BY
}

\author{
R. R. WILLCOX
}

St. Mary's Hospital, London

A total of 158 cases of non-gonococcal urethritis has been treated with erythromycin or tetracycline hydrochloride administered orally. Patients who had been previously treated, or had been given less than $6.0 \mathrm{~g}$. of the antibiotic, have been excluded, and this paper contrasts the results of 62 previously untreated cases given $6.0 \mathrm{~g}$. erythromycin (as $300 \mathrm{mg}$. four times a day for 5 days) with those of 58 previously untreated cases given $6.0 \mathrm{~g}$. tetracycline (as $250 \mathrm{mg}$. four times daily for 6 days).

\section{Material}

Of the 120 patients examined, 101 were white-s' ${ }^{\prime}$ inned, fifteen were Negroes, two were from Ceylon, one from India, and one from Burma ; 57 were married, 62 were single, and one was separated from his wife. Their average age was 31 years (extremes 20-56). Only 43 had had no previous venereal disease, and the remaining 77 had had between them no fewer than 69 attacks of gonorrhoea, 66 of non-specific urethritis (including one attack of Reiter's syndrome), three of syphilis, three of herpes genitalis, and one each of soft sore, balanitis, and genital molluscum contagiosum.

Of the nineteen non-white persons, six had had no previous trouble, but the remaining thirteen had had nineteen attacks of gonorrhoea, ten of non-specific vrethritis, one of syphilis, and one of molluscum contagiosum. The average number of previous infections was thus 1.6 for the non-white and 1.1 for the whiteskinned persons.

The infection was acquired from a stranger in 55 cases, from a friend in 39 , from the wife in 23 , and there was no record in three cases. Of the 57 married patients, the infection was apparently acquired from a stranger in 21 cases, from a friend in fourteen, and from the wife in 22 .

The apparent incubation period was 1 to 7 days in 46 cases, 8 to 14 days in 21,15 to 21 days in eight, 22 to 28 days in six, and over 1 month in six. The incubation period was impossible to assess in 33 cases.

The symptoms had been present before treatment for 1 to 3 days in 54 cases, 4 to 7 days in 21,1 to 2 weeks

* Received for publication June 13, 1955.

+ Presented at the Seventh Annual Symposium on Recent Advances in the Study of Venereal Diseases, Washington, D.C., April, 1955. in 24, and more than 2 weeks in 21. Dysuria was present in 67 cases and absent in 53.

Gonococci were excluded in the urethral smears of all cases. The Wassermann and VDRL (Harris) tests were both negative in 114 patients, the Wassermann test negative and the Harris doubtful in four, and both tests positive in two. The gonococcal complementfixation test was performed on serum from 104 patients : it was negative in 97 , doubtfully positive in one, positive in five, and anticomplementary in one.

\section{Results}

The results are shown in Tables I and II. In assessing the failure rates, all suspected re-infections occurring within the three post-treatment months have been classified as failures. Re-infections occurring after 3 months (the prescribed period of follow-up) have been excluded.

\section{TABLE I}

RESULTS IN ERYTHROMYCIN-TREATED CASES (6.0 g. over 5 days)

\begin{tabular}{|c|c|c|c|c|}
\hline Follow-up & $\begin{array}{l}\text { No. } \\
\text { Followed }\end{array}$ & $\begin{array}{l}\text { No. of } \\
\text { Failures }\end{array}$ & $\begin{array}{c}\text { No. of } \\
\text { Re-infections }\end{array}$ & $\begin{array}{c}\text { Cumulative } \\
\text { Percentage } \\
\text { Failing } \\
\text { (including } \\
\text { Re-infection) }\end{array}$ \\
\hline $\begin{array}{l}0 \\
1-3 \text { days }\end{array} \quad \ldots$ & $\begin{array}{r}62 \\
57 \\
56 \\
46 \\
40 \\
35 \\
30 \\
21 \\
7\end{array}$ & $\begin{array}{l}- \\
- \\
3 \\
2 \\
3 \\
2 \\
- \\
-\end{array}$ & $\begin{array}{l}- \\
\bar{E} \\
\overline{1} \\
1 \\
1\end{array}$ & $\begin{array}{r}- \\
\overline{5 \cdot 4} \\
9 \cdot 7 \\
17 \cdot 2 \\
25 \cdot 8 \\
27 \cdot 1 \\
33 \cdot 9 \\
-\end{array}$ \\
\hline Total & - & 10 & 3 & - \\
\hline
\end{tabular}

Overall failure rates at 2 to 3 months : $22 \cdot 8$ per cent. of those followed.

While failure rates tend to increase as greater numbers are treated and a more prolonged follow-up is obtained, it will be noted that the cumulative failure rate at 2 to 3 months so far compares with a cumulative failure rate of 25.5 per cent. with $6.0 \mathrm{~g}$. oxytetracycline or $6.0 \mathrm{~g}$. chlortetracycline-both in previously untreated cases (Willcox, 1955). 
TABLE II

RESULTS IN TETRACYCLINE-TREATED CASES (6.0 g. over 6 days)

\begin{tabular}{|c|c|c|c|c|}
\hline Follow-up & $\begin{array}{l}\text { No. } \\
\text { Followed }\end{array}$ & $\begin{array}{l}\text { No. of } \\
\text { Failures }\end{array}$ & $\begin{array}{c}\text { No. of } \\
\text { Re-infections }\end{array}$ & $\begin{array}{c}\text { Cumulative } \\
\text { Percentage } \\
\text { Failing } \\
\text { (including } \\
\text { Re-infection) }\end{array}$ \\
\hline $\begin{array}{ll}0 & \ldots \\
1-3 \text { days } & \ldots \\
4-7 \text { days } & \ldots \\
8-14 \text { days } & . \\
15-21 \text { days } & . \\
22-28 \text { days } & \ldots \\
1-2 \text { months } & . \\
2-3 \text { months } & \\
\text { Over } 3 \text { months }\end{array}$ & $\begin{array}{r}58 \\
52 \\
51 \\
42 \\
35 \\
30 \\
26 \\
10 \\
3\end{array}$ & $\begin{array}{l}- \\
\frac{1}{1} \\
2 \\
- \\
-\end{array}$ & $\begin{array}{l}- \\
\bar{E} \\
\frac{1}{E} \\
(2)\end{array}$ & $\begin{array}{r}- \\
\overline{2 \cdot 0} \\
2 \cdot 0 \\
7 \cdot 7 \\
14 \cdot 4 \\
29 \cdot 8 \\
- \\
-\end{array}$ \\
\hline Total & - & 8 & 1 & 一 \\
\hline
\end{tabular}

Overall failure rate at 2 to 3 months : $17 \cdot 3$ per cent. of those followed.

Failures.-The average age of the failures was 31.1 years-approximately that of the average of the whole. Failure was not related to race, marital status, previous venereal disease, or to the results of the serum tests for syphilis and gonorrhoea. Likewise, when the failures were related to mode of infection, the presence or absence of dysuria, or to the apparent incubation period, nothing significant was noted. However, when the failures were related to the duration of symptoms before treatment, it was found that proportionately fewer failures were noted in patients in whom the discharge had been present for more than 1 week before treatment than in those in whom it had been present for 1 week or less (Table III).

TABLE III

FAILLRES RELATED TO DURATION OF SYMPTOMS BEFORE TREATMENT

\begin{tabular}{|c|c|c|c|c|}
\hline $\begin{array}{l}\text { Duration of } \\
\text { Symptoms } \\
\text { (weeks) }\end{array}$ & $\begin{array}{c}\text { No. } \\
\text { Treated }\end{array}$ & $\begin{array}{l}\text { No. } \\
\text { Followed }\end{array}$ & $\begin{array}{l}\text { No. of } \\
\text { Failures }\end{array}$ & $\begin{array}{l}\text { Percentage } \\
\text { Failing } \\
\text { of those } \\
\text { Followed }\end{array}$ \\
\hline 1 or less & 75 & 67 & 18 & $26 \cdot 9$ \\
\hline More than 1 .. & 45 & 42 & 3 & $7 \cdot 1$ \\
\hline Total & 120 & 109 & 21 & $19 \cdot 3$ \\
\hline
\end{tabular}

This difference may be due to the fact that persons who tolerate a discharge for some time before treatment are less critical and less likely to complain about a minor relapse later.

Side-effects.-Mild side-effects of diarrhoea, occasional rectal soreness, nausea, etc., followed the general pattern experienced with chlortetracyclinc or oxytetracycline. Of the 120 patients, only one (treated with erythromycin) failed to take the prescribed course.

\section{Summary}

(1) The results are presented of treating 62 previously untreated cases of non-gonococcal urethritis with $6.0 \mathrm{~g}$. erythromycin and of treating 58 previously untreated cases with the same dose of tetracycline.

(2) Of the 57 erythromycin-treated cases followed, there were 13 failures $(22.8$ per cent.). Of the 52 tetracycline-treated cases followed, there were nine failures (17.3 per cent.). When the results were accumulated to take into account differences in follow-up, the cumulative failure rate was 33.9 per cent. for those treated with erythromycin and 29.8 per cent. for those treated with tetracycline.

(3) Patients in whom the symptoms had been present for more than 1 week apparently responded better than those in whom the symptoms had been present for 1 week or less.

(4) Side-effects were relatively few and mild.

Grateful acknowledgments are expressed to Eli Lilly and Co. Ltd. of Basingstoke, England, and Charles Pfizer Ltd. of Folkestone, England, for so kindly providing the erythromycin ("Ilotycin") and tetracycline ("Tetracyn ") used in this study.

\section{REFERENCE}

Willcox, R. R. (1955). British Journal of Venereal Diseases, 31, 89. 